\title{
Harmful Algal Blooms, Cause, Purpose and Solution from the Qur'anic Viewpoint and Marine Science: An Environmental Discourse
}

\section{${ }^{1}$ Md. Sirajul Islam ${ }^{2}$ Sofiah Bt. Samsudin}

${ }^{1}$ Md. Sirajul Islam Ibn Sultan Ahmad, Ph.D. candidate, Department of Qur'an \& Sunnah Stuidies, Kulliyyah of Islamic Revealed Knowledge and Human Sciences, International Islamic University Malaysia, 53100 Jalan Gombak, Selangor, Kuala Lumpur, Malaysia.

${ }^{2}$ Assistant Prof. Dr. Sofiah Bt. Samsudin, Department of Qur'an \& Sunnah Studies, Kulliyyah of Islamic Revealed Knowledge and Human Sciences, International Islamic University Malaysia, 53100 Jalan Gombak, Selangor, Kuala Lumpur, Malaysia.

Correspondence Author: Md. Sirajul Islam, Md. Sirajul Islam Ibn Sultan Ahmad, Ph.D. candidate, Department of Qur'an \& Sunnah Studies, Kulliyyah of Islamic Revealed Knowledge and Human Sciences, International Islamic University Malaysia, 53100 Jalan Gombak, Selangor, Kuala Lumpur, Malaysia.

E-mail: sirajulislam1981@yahoo.com

Received date: 23 February 2018, Accepted date: 23 April 2018, Online date: 28 April 2018

Copyright: (C) 2018 Md. Sirajul Islam and Sofiah Bt. Samsudin. This is an open-access article distributed under the terms of the Creative Commons Attribution License, which permits unrestricted use, distribution, and reproduction in any medium, provided the original author and source are credited.

\begin{abstract}
Currently almost every seaside country in the world is affected by Harmful Algal Blooms (HABs), commonly called "red tides". This diverse array of phenomena includes blooms of toxic, microscopic algae that lead to illness and death in humans, fish, seabirds, marine mammals and other oceanic life forms. There are also non-toxic HABs that cause damage to ecosystems, fisheries resources and recreational facilities. It is responsible for economic losses in coastal states. The aim of this study is analyze what is the HABs from the Qur'anic viewpoint and modern marine science as well as detect why appears such a disaster in costal and what is its solve from the Qur'anic standpoint. As a result, the study found that the Holy Qur'an has mentioned (al-fasad) disasters to refer to numerous kinds of calamities, contaminations and pollutions in sea including the HABs. Also, it included historical, current and whatever new form of disaster will appear in future both in land and sea. As a cause for the HABs the study found Almighty Allah mentioned cause and 2 purposes for HABs in the sea: HABs are reaction of humans' wrongdoing; HABs are to give punishment the Humans for their immoral actions; HABs are to return to the right way. Similarly, it found integration between the Qur'anic viewpoint and modern marine science in HABs that "Humans' activities profoundly affect the amount of fresh water which reaches the coast, and this can enhance HABs".
\end{abstract}

Key words: Harmful Algal Blooms, Qur'anic Viewpoint, Marine Science, Human activities, Microscopic algae, Return to the right way.

\section{INTRODUCTION}

Huge accumulations of microalgae, phytoplankton and in frequently colorless heterotrophic protists are increasingly reported all over the seaside of all continents around the world. Aggregation of these organisms could contribute to make dis-color the fresh water by increasing the color such as red, brown, mahogany or green tides can float on the surface in scums, covering beaches with biomass or exudates (foam)as well as deplete oxygen levels through excessive respiration or decomposition. Alternatively, certain species in harmful algal blooms (HABs) can show float their effects through the synthesis of compounds (e.g., toxins) that can alter cellular process of other organisms from plankton to humans. The most acute effects of HABs include fish, bird, and mammal including human mortalities, respiratory or digestive tract problems, lesions and skin irritation, seizures, memory loss, as well as losses of coastal resources [13].

Harmful Algal Bloom and Hypoxia Research and Control Act of 1998 [P.L. 105-383] stated that "Congress finds that., Harmful Algal Blooms have been responsible for an estimated $\$ 1,000,000,000$ in economic losses during the past decade." [8]. In addition, an another study has been estimated that almost US $\$ 49$ million was lost annually to HABs-related impacts in the United States over a 5 years study period (1987-1992)[13].Economists focused on three major aspects of HABs: (1)the negative regional economic impacts due to HABs; (2) the economic costs of human illness caused by HABs; and (3) human perceptions of risks associated with seafood due to HABs [36].

According to Anderson, D. M., \& Garrison, D. J. it is a significant challenge to those responsible for the management of seaside resources threatened by the variety in Harmful Algal blooms and their current affects. The strategies required to protect fisheries, decrease economic, ecosystem damages and protect peoples' health vary considerably among locations and among HAB types. We don't have all of the knowledge we essential to comprehend about why HABs form in many areas. Therefore, it is obviously difficult to regulate or control those factors [6].

However, there are many studies have been conducted by researchers in HABs in the coastal zone and its causes. What about HABs in the Holy Qur'an? Has any information or example of HABs, its cause, purposes and HABs management issues in the Holy Qur'an? Yes! Almighty Allah says "Indeed We have explained in this Qur'an every subject in various ways for the benefit of the people” [Al-Qur'an 18:54]. In the Holy Qur'an a total of 6,236verses are evidence of not only 6,236 ideas, subjects and issues but also evidence on endless ideas, subjects, and issues and so on. Applying appropriately these verses in solving problems, discovering new items and establishing new ideas depends on scholars' intelligence, thinking power, contemplation, realization, intellectuality, valid arguments and so forth. Following this statement this study will derive the HABs, causes and its solve from the Holy Qur'an. 
Citation: Md. Sirajul Islam and Sofiah Bt. Samsudin, 2018. Harmful Algal Blooms, Cause, Purpose and Solution from the Qur'anic Viewpoint and Marine Science: An Environmental Discourse. Advances in Environmental Biology., 12(4): 12-19.

2. Discussion:

The discussion has been done by following three important questions; what is HABs, why appears HABs in the sea, and what is its solve respectively.

\subsection{What is Harmful Algal Blooms (HABs):}

HABs have been described in this study from the Qur'anic and marine scientist's perspective.

2.1.1 Harmful Algal Blooms (HABs) in the Holy Qur'an.

2.1.2 Harmful Algal Blooms (HABs) according to marine scientists.

\subsubsection{Harmful Algal Blooms (HABs) in the Holy Qur'an:}

Each Islamic scholar has academic responsibility to recognize the problem, its causes and find way of solving the recognized problems in his time from the Islamic standpoint. The study has identified Harmful Algal Blooms is a natural environmental pollution, hence tried to understand the issue in order to obtain valid facts in establishing principles from the Qur'an. Almighty Allah says, "Calamities (disasters) have appeared on land and sea because of what the hands of the people have earned, so that He (Allah) makes them taste some of what they did, in order that they may return (to the right way)”[Al-Qur'an- 30: 41] [16].

\section{Interpretation of the Qur'anic terminology al-fasad (Calamities or disasters) in sea:}

There are various interpretations among scholars about calamities in sea these can be summarized as follows:

Al-Nuhas said: calamity in sea is severance in hunting (Al-Qurtubi, A. M. Vol.14, P. 40) [4]. Ibn Atiyah said: whenever decrease rain consequently decrease diving of fish, marine mammals, and other oceanic life into sea, and hunters become fail in their hunting, and the sea beasts become blind (Al-Qurtubi, A. M. Vol.14, P 40) [4]. Ibn Abbas said: after raining from the sky shells open in sea, and whatever grows up in shells from the sky that is pearl (Al-Qurtbi, A. M. Vol.14, p 40) [4]. Ibn Ajibah said: a lot of sink and severance in hunting (Ibn Ajibah, A.I.M vol.5, P. 12) [9]. Muhammad Asad's comments about disaster in sea are increasing ecological disasters, contamination water, a progressive poisoning of marine life and the gradual death of many life forms essential to human wellbeing [12].

Table 1: Calamities in the sea in light of interpretation of the Qur'anic terminology al-fasad (Calamities or disasters) in sea

\section{Calamities in the sea}

1. Severance in hunting

2. Sea beasts becoming blind

3. A lot of sink

4. Ecological disasters

5. Contamination water

6. Poisoning of marine life

7. Death of many marine life forms

The table shows this study finds 7 disasters in sea in light of interpretation of the Qur'anic terminology al-fasad (Calamities or disasters) in sea. Without disaster no 3, other 6 disasters related to Harmful Algal Bloom. In a short, severance in hunting, sea beasts becoming blind, contamination water, poisoning of marine life, death of many marine life forms are cause for HABs. In fact, the Holy Qur'an it has owns style of dealing with the facts and principles of science. It is an example on its style that in the Holy Qur'an has mentioned disasters (al-fasath) to refer to all types of calamities, contaminations and pollutions in sea including the HABs. Also, it included historical, current and whatever new form of disaster will appear in future both in land and sea. It is a miracle of the Holy Qur'an in revealing the message, wisdom in using appropriate terminology and insight in conveying information related to subject.

\subsubsection{Harmful Algal Blooms (HABs) according to marine scientists:}

HABs usually called red tides, are aquatic phenomena frequently marked by the discoloration of surface waters due to the rapid growth and gathering of certain microalgae, several of which produce highly potent toxins. Thus, HABs can have severe impacts on marine organisms, important industries and public health, (e.g. Mariculture, shell fisheries, tourism), and the quality of freshwater reservoirs and coastal environments [25]. Harmful algal blooms (HABs) are a global hazard to living oceanic life forms and human health. These events impact all coastal U.S. states (Figure 1) and great portions of seaside Canada and Mexico [36]. In October 2011, thick bright green algae roofed over 3200 square kilometers of Lake Erie (Figure 2, 3). It was considered as a biggest harmful algae bloom in the lake's recorded history. The bloom was made up mostly of toxic blue-green algae [37].

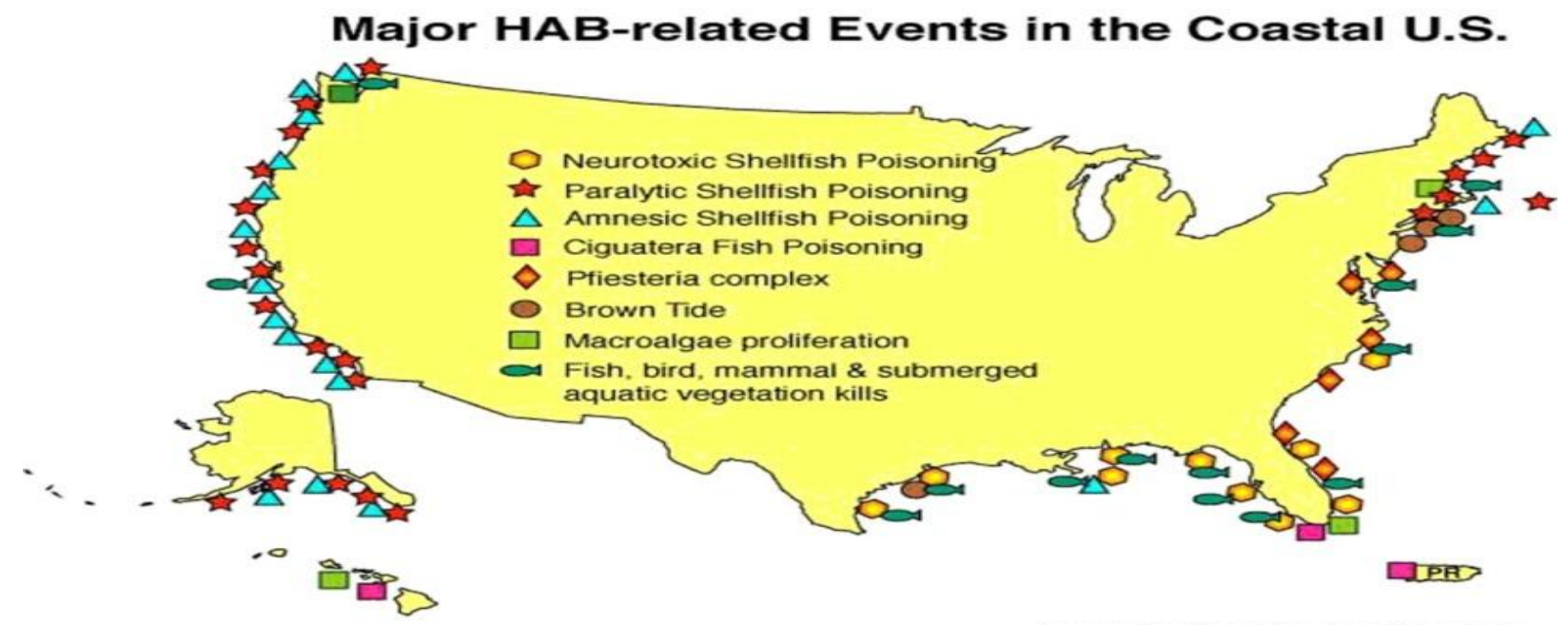

Fig. 1: Major Harmful Algal blooms events in the Coastal U.S.A, image by Glenda Powell 2005. 


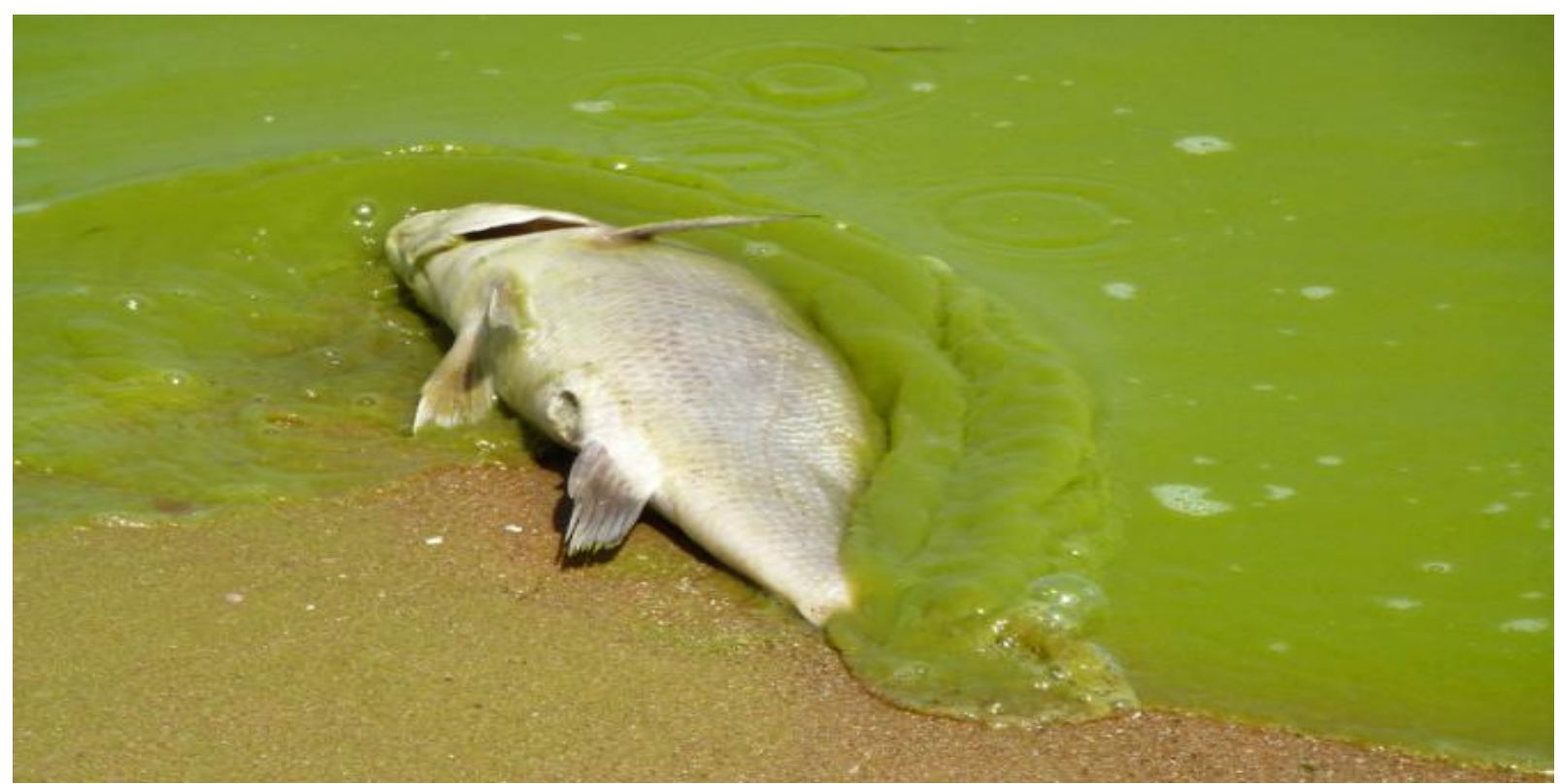

Fig. 2: This photo of the record-setting 2011 Lake Erie algae bloom was taken in August of that year along the southeast shore of pelee Island, Ontario. Tom Archer, Handout.

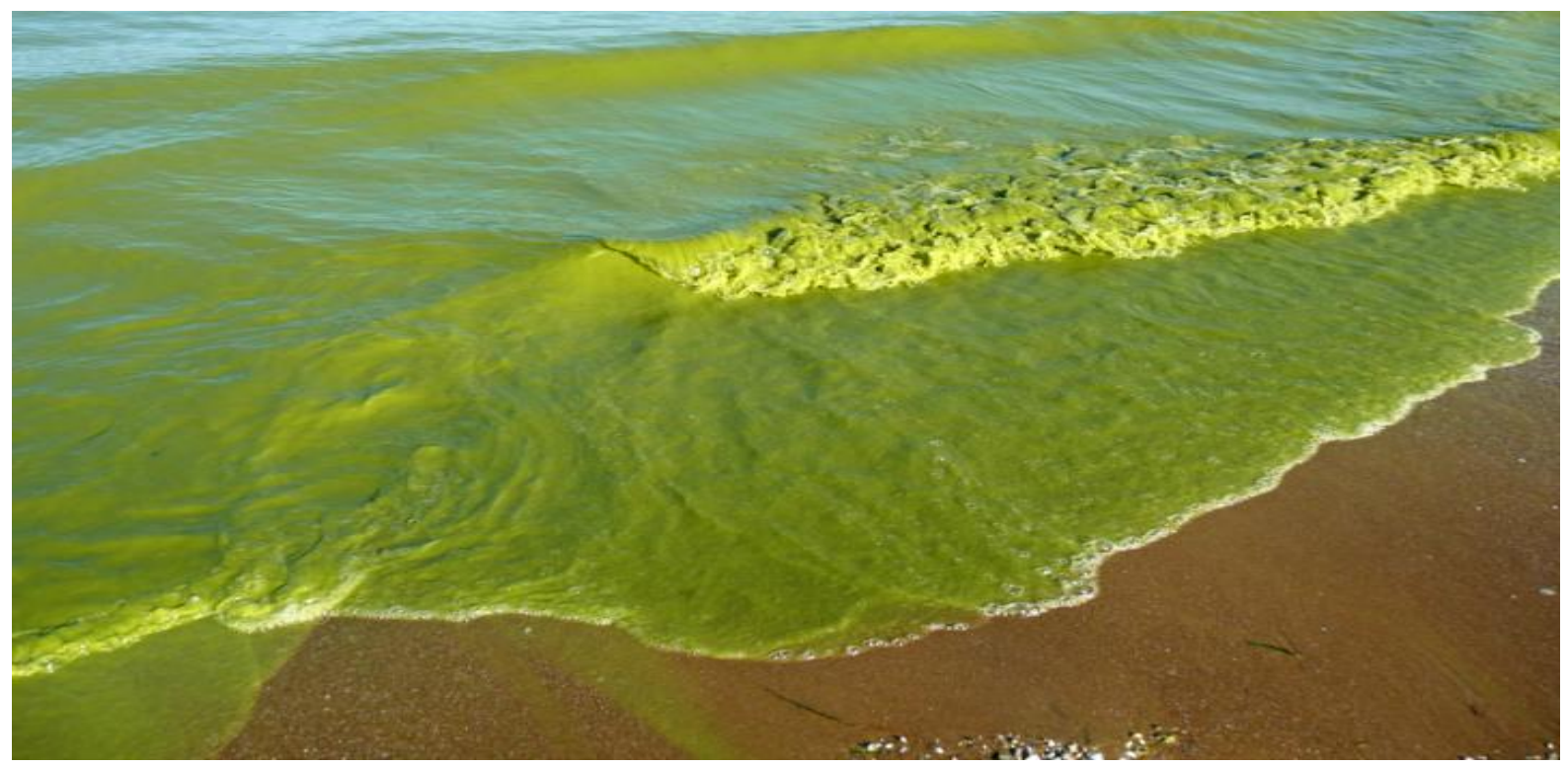

Fig. 3: Blue-green algae at beach, Tom Archer, handout.

Anderson and Hallegraeff says "Several decades ago, relatively few countries were affected by HABs, [6]. In addition, about current situation Anderson said: "But now almost every seaside country in the world is affected by harmful algal blooms (HABs, commonly called "red tides") (figure 4). This diverse array of phenomena includes blooms of toxic, microscopic algae that lead to illness and death in humans, fish, seabirds, marine mammals, and other oceanic life (figure 5). There are also non-toxic HABs that cause damage to ecosystems, fisheries resources, and recreational facilities, often due to the sheer biomass of the accumulated algae. The term "HAB" also applies to non-toxic microalgae (seaweeds), which can cause major ecological impacts such as the displacement of indigenous species, habitat alteration and oxygen depletion in bottom waters. The frequency, spatial extent, and economic impact of HAB have all expanded in recent decades, in parallel with, and sometimes a result of, the world's increasing exploitation on the coastal zone for shelter, food, recreation, and commerce" [6, 23].

Senior Scientist Donald M. Anderson and Garrison say "HABs events are characterized by the proliferation and occasional dominance of particular species of toxic or harmful algae. In some cases, these microscopic cells increase in abundance until their pigments discolor the water - hence the term «red tide». There are, however, "blooms" of species which do not have high cell concentrations, and which do not discolor the water, but which still cause harm, typically because of the potent toxins produced by those algae. The term "harmful algal bloom" is very broad and covers blooms of many types, but HABs all have one unique feature in common they cause harm, either due to their production of toxins or to the manner in which the cells' physical structure or accumulated biomass affect co-occurring organisms and alter food-web dynamics [6]. According to Hallegraeff "HABs in a strict sense are completely natural phenomena that have occurred throughout recorded history. Even nontoxic algal blooms can have devastating impacts, for instance, when they lead to kills of fish and invertebrates by generating anoxic conditions in sheltered bays. Other algal species, even though nontoxic to humans, can produce exudates or reactive ox ygen species that can damage the gill tissues of fish (raphidophytes Chattonella and Heterosigma, and dinoflagellates Cochlodinium, Karenia, and Karlodinium). Whereas wild fish stocks can swim away from problem areas, caged fish in intensive aquaculture operations are trapped and thus can suffer catastrophic mortalities. Of greatest concern to human society are algal species that produce potent neurotoxins that can find their way through shellfish and fish to human consumers where they produce a variety of gastrointestinal and neurological illnesses. One of the first recorded fatal cases of food poisoning after eating contaminated shellfish happened in 1793, when English surveyor Captain George Vancouver and his crew landed in British Columbia (Canada) in an area now known as Poison Cove" [24]. 
Citation: Md. Sirajul Islam and Sofiah Bt. Samsudin, 2018. Harmful Algal Blooms, Cause, Purpose and Solution from the Qur'anic Viewpoint and Marine Science: An Environmental Discourse. Advances in Environmental Biology., 12(4): 12-19.

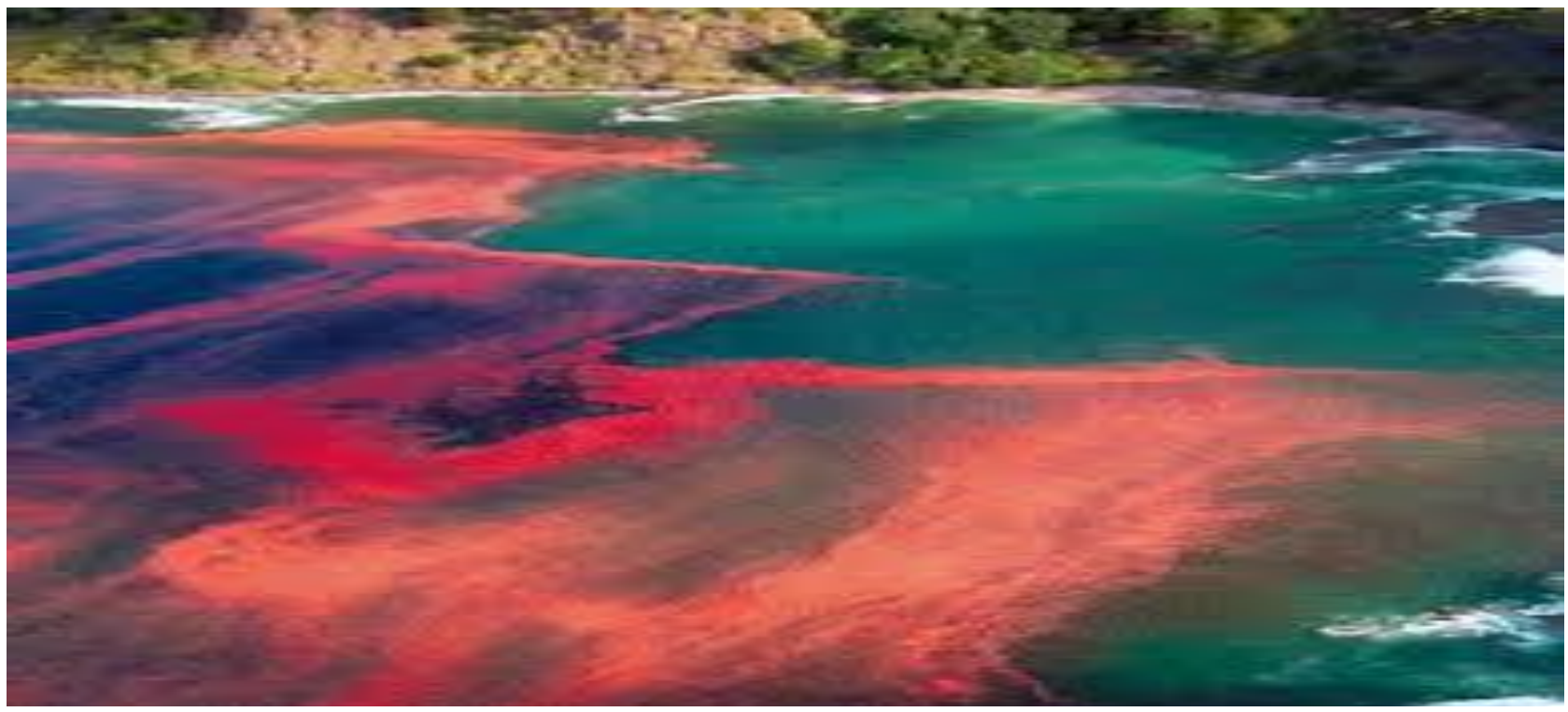

Fig. 4: A "red tide bloom" of Noctilucascintillans in New Zealand. Photo credit: M. Godfrey

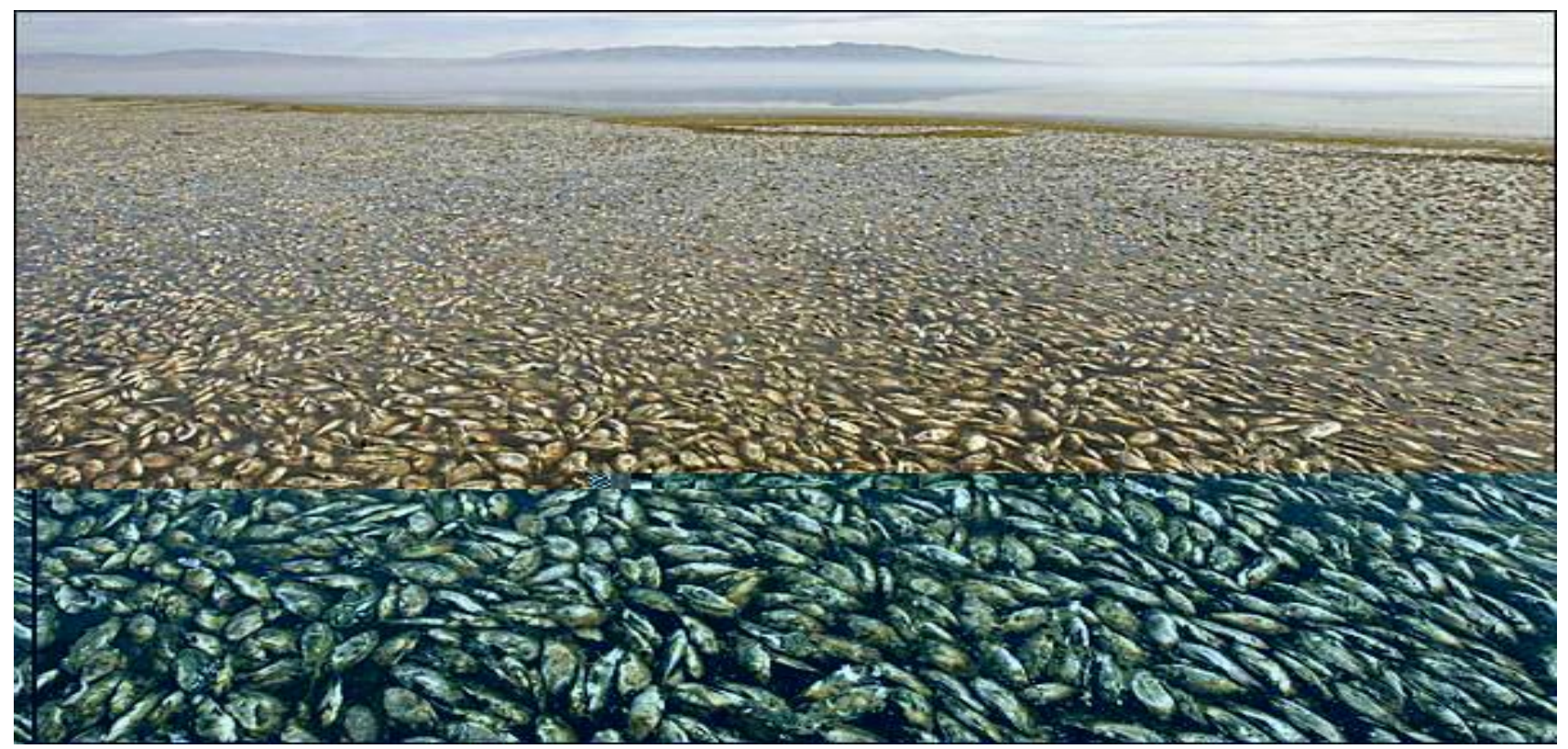

Fig. 5: Fish die cause for red tide bloom

\subsection{Why appears Harmful Algal Blooms $(H A B)$ in the sea:}

The study strives to diagnose the root reason for HABs because of could not real solution of problem unless could detect the root reason. Therefore, the study explores in the Holy Qur'an to identify the main reason for HABs. It found Almighty Allah mentioned 2 major things in HABs as follows:

2.2.1 Cause.

2.2.2 Purposes.

2.2.1 Cause for HABs in the light of the Holy Qur'an:

HABs are reaction of humans' actions, Almighty Allah says: "Disasters have appeared on land and sea because of what the hands of the people have earned" [the Holy Qur'an 30: 41] [16].

Explanation in the the Qur'anic statement:

Al-Nuhas said: Cause for disasters in sea is result of fault by sons of Adam (Al-Qurtbi, A. M. Vol.14, p 40) [4].Ibn Ajibah said: Cause for disasters in sea is cause of unbelief and $\sin$ (unbelief is cause for $\sin$ and $\sin$ is cause for calamities) (Ibn Ajibah, A.I.M., vol.5 and p12) [9]. Muhammad Asad says: as a result of an uncontrolled contamination of land, water, air, a progressive poisoning of plant and the gradual death of many animal species essential to human well-being [12]. An outcome of what men's hands have produced that is self-destructive such as extremely materialistic notion, inventiveness and frenzied activity, industrial and urban waste, all manner of genetic malformations in men's own bodies through an ever-widening use of drugs and seemingly "beneficial" chemicals, the all-round increase in sexual perversion, crime and violence, with, perhaps, nuclear annihilation as the ultimate stage, all of which is, in the last resort, an outcome of man's oblivion of Allah [12].

Cause for HABs according to marine scientists:

In addition, modern marine scientists have discovered the causes of HABs which have been included in the Qur'anic statement. For instance, Anderson, Smayda and Hallegraeff enunciate that causes behind growth of HABs are debated, with possible explanations ranging from natural mechanisms of species dispersal and enhancement of human beings related phenomena such as pollution-related nutrient enrichment, climatic shifts, or transport of algal species via ship 
ballast water [6, 28, 29].Humans' activities can profoundly affect the amount of fresh water that reaches the coast, and this can enhance HABs [6].There is strong evidence that coastal eutrophication contributes to increase incidence of certain HABs in seaside [29,30,31, 32,33,34].Merely a small constituent of the phytoplankton community construct Harmful Algal species, and their individual reactions to climate variation can differ from that of the phytoplankton community as a whole. In freshwater, the most important HABs are produced by certain species of cyanobacteria (blue green algae) from the genera Anabaena, Microcystis,and Aphanizomenon (cyanobacterial poisoning) [26, 27].It is mostly accepted that HABs events are gradually increasing in frequency, intensity, and duration in all aquatic environments on a global scale [26, 29,35], and several of this may be due to changes in climate [26].

Disasters have been mentioned in the Holy Qur'an both on land and sea. In fact, there has information for ecologist what is the philosophy in mention land before sea. Almighty Allah says: "Calamities (disasters) have appeared on land and sea because of what the hands of the people have earned, so that He (Allah) makes them taste some of what they did, in order that they may return (to the right way)" [Al-Qur'an- 30: 41] [16]. Really, it is the Qur'anic wisdom. Humans are living in the land, and their activities are directly impacting in social and natural ecosystems. Consequently, first of all, disasters are appearing in the land and terrestrial bionetwork then it effect on marine resources (Figure 6).

This statement would make easy to understand the Qur'anic information about cause and purpose in disaster in land and sea. "Human activities lead to pressures on the natural system, which in turn change its state, properties and processes of the ecosystem. The state changes in the natural system are finally resulting in impacts to the human system and to the way we can use the natural resources (as ecosystem services). Society then finds a response with e.g. implementing appropriate policy that is meant to change the nature and magnitude of the human activities associated to the drivers" $[17,18,19,20$ and 21$]$.

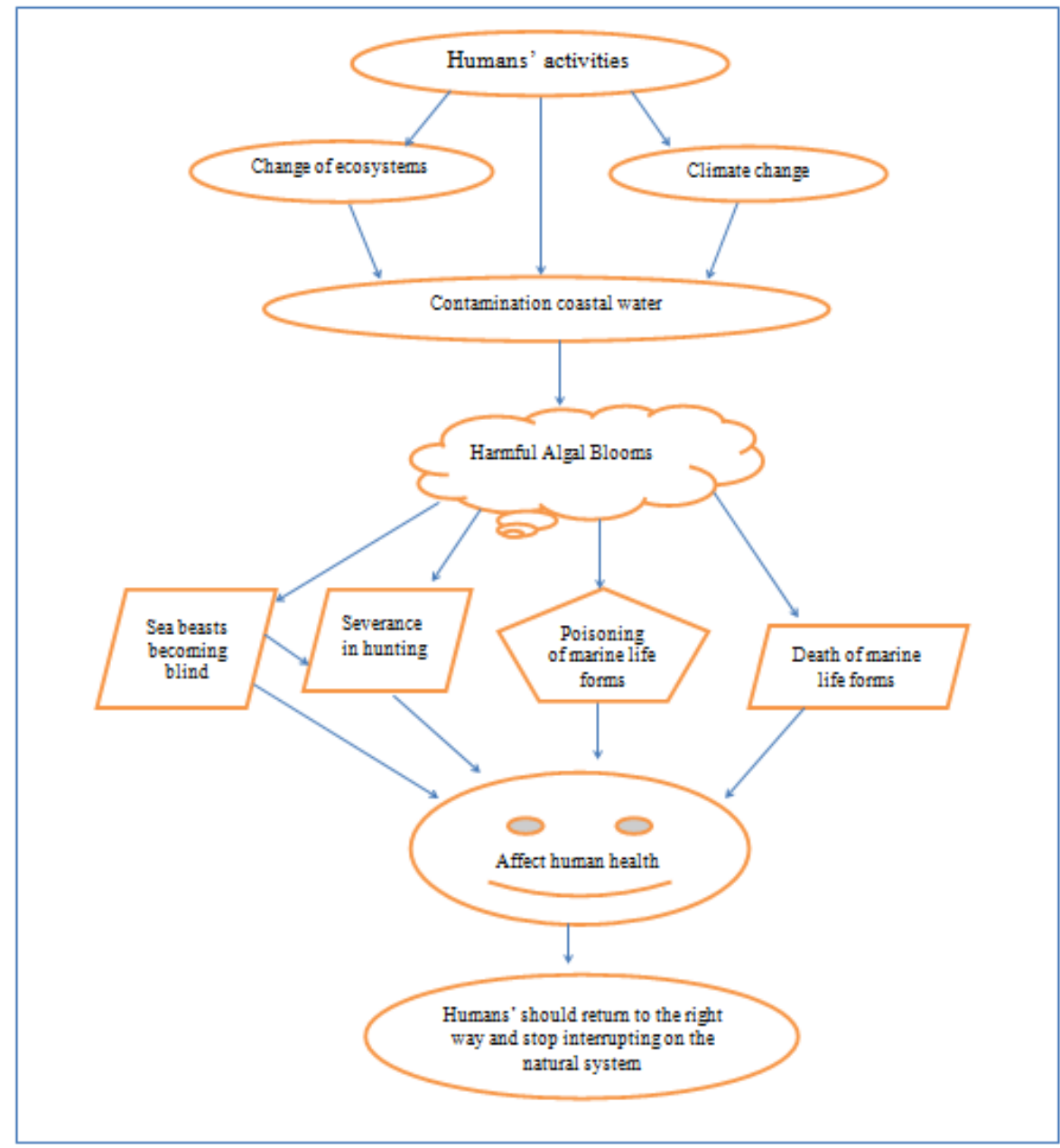

Fig. 6: human wrongdoings first of all impact in the land and terrestrial bionetwork then it effect in marine resources

\subsubsection{Purposes of HABs in the light of the Holy Qur'an:}

2.2.2.1 HABs are to give punishment the Humans for their wrongdoing actions:

Almighty Allah says: "Disasters have appeared on land and sea because of what the hands of the people have earned, so that He (Allah) makes them taste some of what they did" [The Holy Qur'an 30: 41][16].Ibn Ajibah said: calamities appears for testing evil result of their actions in the here before giving them all punishment in the hereafter (Ibn Ajibah, A.I.M., vol.5 and p13) [9].

2.2.2.2 HABs are in order to return to the right way:

Almighty Allah says: "Calamities (disasters) have appeared on land and sea because of what the hands of the people have earned, so that He (Allah) makes them taste some of what they did, in order that they may return (to the right way)" [Al-Qur'an- 30: 41] [16]. Ibn Ajibah said: As though they may return to the right way from wrongdoing (figure 7) (Ibn Ajibah, A.I.M., vol.5 and p13) [9]. 


\section{Harmful Algal Blooms (HAB) in the sea}

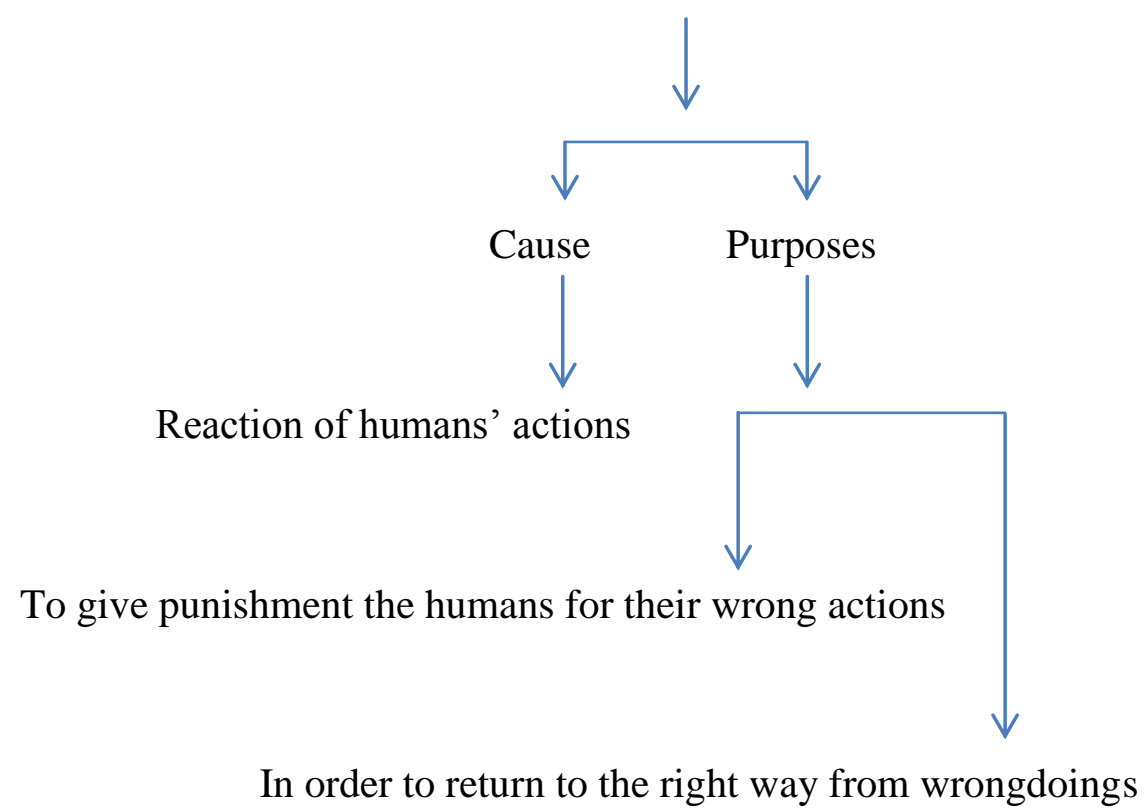

Fig. 7: Why appears Harmful Algal Blooms in the sea? To give answer to this question, the figure shows HAB is reaction of humans' actions; it is to give punishment the humans for their bad actions, and this penalty is to return to the right way.

\section{What is solve of HABs:}

The study focuses on three major points in solving the HABs as follows:

3.1 Doing obedience of Allah.

3.2. Prevention of water from pollution.

3.3 Prevention of water from excessive.

\subsection{Doing obedience of Allah:}

Ibn Ajibah said if humans doing obedience of Allah definitely Allah will remove these epidemics from them (Ibn Ajibah, A.I.M., vol.5 and p12) [9]. Undoubtedly, in the light of the Holy Qur'anic philosophy we belief that causes for HABs are humans' activities, Allah says: 'Do not make mischief on the earth after it has been set in order. And Supplicate Him in fear and hope. Surely, the mercy of Allah is close to those who are good in their deeds". [The Holy Qur'an 7: 56] [16]. Abu Ja'far al-Tabary said, in interpretation of saying of Allah: "Do not make mischief on the earth after it has been set in order" means do not make partner with Allah (do not be polytheist) nor disobey of Allah, and whoever will polytheism it will be "al-Fasad - mischief" in the earth. And "Ba'da Islahihaafter it has been set in order" after reforming the earth by sending the Messenger of Allah in order to call its inhabitants towards the truth and right way to do worship of Allah (Al-Tabari, J., 2000, vol.12, p487) [5]. Interpreted al-shawkani (1759 - 1834) in his Fathul Qadir: "Do not make mischief on the earth after it has been set in order" [The Holy Qur'an 7: 56] [16] Almighty Allah forbidden in making (Fasad) mischief in the earth face to faces, minor or major, such as killing the human, destroying their houses, cutting off their plant species, differ their rivers. Moreover, (Fasad) mischief in the earth also unbelief in Allah and involve with sin that lead to corruption and mischief in the natural environment and the social environment. And meaning of (Ba'da Islahiha) "after it has been set in order" after it is reforming by sending the Messenger and reveling the books (The Holy Qur'an) as well as memorandum the law [14, 15].

In fact, in the light of the Qur'anic philosophy we are witness to the unexpected natural disasters in several parts around the world. The Holy Qur'an also encourages us to be sensible to our natural environments because in each and every parts of creations have numerous significant goals. All creatures in the universe are ecological interconnected; if anybody does unjust with any parts of nature other parts will take action from us to be change their original nature. Islamic legislation came as general rule for albumenizing's; which is not to cause damage of any kindto the universe. Barely, the Messenger of Allah taught us general principal about nature He said: "Neither do harm nor reciprocate in harm" (Sunnan Ibn Maja, vol. 3, No. 2340, p430) [2].

\subsection{Preserving of water resource from pollution:}

In Islamic guidance for preservation of water resource that is forbidden to pollute the water in any of the causes of pollution, such as urine or excrement in stagnant water resources [1]. Narrated from Abu Huryrah that the Messenger of Allah (May Allah peace be upon him) said: "Do not urinate anybody in stagnant water which is not moving, then wash from it" (Al-Nasaei, 1986. no.400, vol.1, p197) [3]. Water pollution in present time is not only confined to the urine and excrement in water, but also there are others things such as residues of industry, chemicals, toxic, poisonous, ships that sink in the seas, liquefies all have become more dangerous and causes for contaminate the water resource. Furthermore, the effects of war and leave radioactive materials, which are a threat to fish and aquatic organisms, and thus become a danger to the men them self when eaten from marine resource [1, 15]. Sewage, toxic chemicals from industries, land runoff, large scale oil spills, ocean mining and littering also cause for contamination of seawater [38]. Most sources of marine pollution are land based [39, 40], such as windblown debris, industrial / domestic pollutants discharged and potential spillovers from freight/ bulk ocean carriers. Other factors causing marine pollution are direct discharge of industrial waste \& sewerage, land run of ship pollution, atmospheric pollution, deep sea mining, acidification, eutrophication, marine fish production, plastic debris [40]. Similarly, an important and worrying cause of marine pollution is oil spills [41]. Aliağa are the chief cause of marine pollution [42]. Waste water disposed into the sea without any treatment is the main cause of marine pollution [43]. Petroleum is shown to be a significant cause of marine pollution since the second quarter of 20th century [44]. Also, tar substance is the major cause for marine pollution [45]. There is countless number of anthropogenic chemicals and radiation that has become the core cause of marine pollution [46].

\subsection{Preserving of water from excessive:}

That the Messenger of Allah peace be upon him passing the Sa'd when he was doing an ablution, He (the Messenger of Allah) said: 'What is this wasting? He (Sa'd ) said: Is wasting in ablution also? He (the Messenger of Allah) said: Yes, even you are in running river» (Sunan ibn Majah, no. 328, vol.1, p119) [2]. 


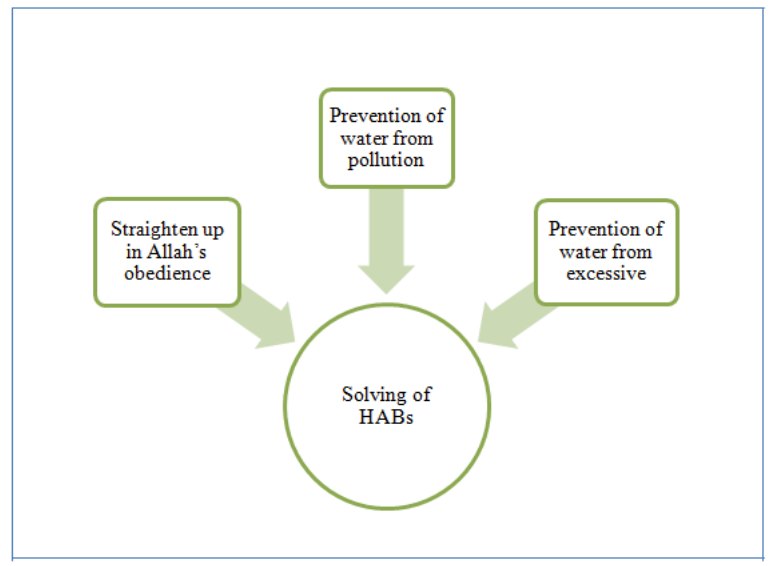

Fig. 8: Solving of HABs

4. Recommendations:

Table 2: Key requirements to solve the HABs hazards

1. Performing commands of Allah and avoiding all that He prohibits including subjects which related to resources and environment.

2. Performing commands of the Messenger of Allah and avoiding all that He prohibited including subjects which related to resources and environment.

3. Following the scientist's instructions in minimizing causes of the HABs.

4. People should obtain basic knowledge about ecosystems and environmental ethics.

5. Stopping permanently the nuclear testing in sea.

6. Preserving of water from pollution and excessive.

7. Increasing the global effort in minimizing the causes of the HABs.

Conclusion:

Disasters (al-fasath) have been mentioned in the Holy Qur'an to refer to all types of calamities, contaminations and pollutions in sea including the HABs. Also, it included historical, current and whatever new form of disaster will appear in future both in land and sea. Also, the Holy Qur'an mentions humans are responsible for HABs phenomena. This study found the reality of the Qur'anic statement about HABs through reviewing marine scientists' and researchers' researches. For example, transport of algal species via ship ballast water, discharge of industrial waste and sewerage, land run of ship pollution, atmospheric pollution, deep sea mining, acidification, eutrophication, marine fish production, plastic debris, petroleum, tar substance, anthropogenic chemicals and so on are major cause for Harmful Algal Blooms in all over the seaside of all continents around the world. If humans will not return to the right way from wrongdoings with environment, they will face more dangerous disaster than HABs in the sea in near future. Hence, not only the marine scientists and ecologists are responsible for solving the problems of HABs, but also everybody can contribute through following the environmental ethics. Therefore, it is essential global effort to minimize the hazards of HABs. Allah says: "Do not make mischief in the earth after it has been set in order. And Supplicate Him in fear and hope. Surely, the mercy of Allah is close to those who are good in their deeds". [The Holy Qur'an 7: 56]. The Messenger of Allah (May Allah is peace be upon Him) said, "Neither do harm nor reciprocate in harm". It is possible minimize the HABs if humans follow the divine guidelines and scientist's instructions. Hence, in order to effectively manage the impact of humans actions in environment also need profound understanding the relationship between land and sea. People should obtain basic knowledge about ecosystems and environmental ethics.

\section{ACKNOWLEDGEMENT}

Authors are grateful to Asst. Prof. Dr. Dr. Mohd. Fuad Md. Sawari for his motivation in this study and Prof. Dr. Ibrahim Mohamed Zein, former Dean of Kulliyyah of Islamic Revealed Knowledge and Human Sciences, IIUM for his encouragement. We are grateful to Dr. Maimunahbt. Abdul Kadir from the Department of English Language \& Literature for her inspiration and academic support. They are also thankful to the unknown reviewers for their worthy suggestions that help to improve this manuscript.

\section{REFERENCES}

[1] Al- Qardawi, Y., 2010. Himaytul Byatu fil Islam, Muwssastul Bytu al-Milkiyati fi al-fikri al-Islami- Uman.

[2] Al- Qazuyni, M.I.Y., Sunan ibn Majah, review: Fuad Abdul Baqi, Publisher: Daru al-fikr-Byrut.

[3] Al-Nasai, A.R., 1986. Assunan al- Sugrah lilnnisay, review: Abdul Fatah Abu Ghaddah, publisher, maktab al-matbu"at al- Islamyah, 2nd edition.

[4] Al-Qurtbi, A.M., 2003. al-Jami'liAhkam al-Qur'an, review: Hisham Samir al-Bukhari, publisher: Dar Alam al-Kutub-Riyadh, 14: 40.

[5] Al-Tabari, J., 2000. Jamiul Bayan fi Ta'bil Al-Qur'an, Review by Ahmad Muhammad Shakir, publisher: Muassasatu al-Risalah, $1^{\text {st }}$ edition.

[6] Anderson, D.M. and D.J. Garrison, 1997. Ecology and oceanography of harmful algal blooms.American Society of Limnology and Oceanography.

[7] Ghulsyani, M., 2011. The Holy Qur'an and the Sciences of Nature. Amin research and cultural centre, Kuala Lumpur.

[8] Hoagland, P., D.M. Anderson, Y. Kaoru and A.W. White, 2002. The economic effects of harmful algal blooms in the United States: estimates, assessment issues, and information needs. Estuaries, 25(4): 819-837.

[9] Ibn Ajibah, A.I.M., 2002. Tafsir al-Bahru al-Madid, publisher: Dar al-Kitab al- Ilmiyah- Byrut, $2^{\text {nd }}$ edition, 5 and p12.

[10] Jalaliddin, M. and S. Jalaluddin, tafsir Jalalain (Cairo: Darul hadith, $1^{\text {st }}$ edition), 1: 561.

[11] Akbar Ali, M., M. Shamsher Ali, A.Q. Choudhury, M.A. Jabbar, M. Ferdous Khan, M. Salar Khan, Kh. M. Mannan, M. Ghulam Muazzm and M.M. Salahud din, 1990. Scientific Indications in the Holy Qur'an. Islamic Foundation, Dhaka, Bangladesh.

[12] Muhammad, A., 2007. The e-text version of the book The Message of The Quran.

[13] Sellner, K.G., G.J. Doucette and G.J. Kirkpatrick, 2003. Harmful algal blooms: causes, impacts and detection. Journal of Industrial Microbiology and Biotechnology, 30(7): 383-406.

[14] Shawkani, FathulQadir, 3: 47.

[15] Sofiah, S. and MD. Sirajul I. 2014."Environmental Ethics from the Qur'nic Philosophy." Advances in Environmental Biology, 8.4. 
Citation: Md. Sirajul Islam and Sofiah Bt. Samsudin, 2018. Harmful Algal Blooms, Cause, Purpose and Solution from the Qur'anic Viewpoint and Marine Science: An Environmental Discourse. Advances in Environmental Biology., 12(4): 12-19.

[16] Taqi, U., English Translation of the Holy Qur'an.

[17] Berg, T., K. Fürhaupter, H. Teixeira, L. Uusitalo and N. Zampoukas, 2015. The Marine Strategy Framework Directive and the ecosystem-based approachpitfalls and solutions. Marine pollution bulletin.

[18] Atkins, J.P., D. Burdon, M. Elliott, A.J. Gregory, 2011. Management of the marine environment: integrating ecosystem services and societal benefits with the DPSIR framework in a systems approach. Mar. Pollut. Bull. 62, 215-226. http:// dx.doi.org/10.1016/j.marpolbul.2010.12.012.

[19] European Environment Agency, 2010. The European Environment - State and Outlook 2010: Synthesis.

[20] Gabrielsen, P., P. Bosch, 2003. Environmental Indicators: Typology and Use in Reporting, EEA internal working paper, European Environment Agency.

[21] Kristensen, P., 2004. The DPSIR Framework. Paper Presented at the 27-29 September 2004 Workshop on a Comprehensive/Detailed Assessment of the Vulnerability of Water Resources to Environmental Changes in Africa Using River Basin Approach.

[22] Glenda Powell, 2005. NOAA Oceans and Coasts Service, available in http://www.noaanews.noaa.gov/stories2005/s2416.htm.Retrieved 19 June 2015.

[23] Glibert, P.M., D.M. Anderson, P. Gentien, E. Graneli and K.G. Sellner, 2005. The global, complex phenomena of harmful algal blooms.

[24] Hallegraeff, G.M., 2010. Ocean climate change, phytoplankton community responses, and harmful algal blooms: a formidable predictive challenge1. Journal of phycology, 46(2): 220-235.

[25] Sengco, M.R. and D.M. Anderson, 2004. Controlling harmful algal blooms through clay flocculation1. Journal of Eukaryotic Microbiology, 51(2): 169-172.

[26] Moore, S.K., V.L. Trainer, N.J. Mantua, M.S. Parker, E.A. Laws, L.C. Backer and L.E. Fleming, 2008. Impacts of climate variability and future climate change on harmful algal blooms and human health. Environmental Health, 7(2): S4.

[27] Kite-Powell, H., L.E. Fleming, L. Backer, E. Faustman, P. Hoagland, A. Tsuchiya, L. Younglove, 2008.: Linking the oceans to public health: What is the "human health" in OHH. Environ Health, 7(Suppl2): S6.

[28] Cariton, J.T., J.B. Geller, 1993. Ecological roulette: The Global transport of nonindigenous marine organisms. Science., $261: 78-82$.

[29] Van Dolah, F.M., (2000. Marine algal toxins: origins, health effects, and their increased occurrence. Environmental health perspectives, 108(Suppl 1), 133.

[30] Burkholder, J.M., 1998. Implications of harmful microalgae and heterotrophic dinoflagellates in Management of sutainable fisheries. Ecol AppI 8: S37-S62.

[31] Hallegraeff, G.M., 1993. A review of harmful algal blooms and their apparent global increase. Phycologia, 32: 79-99.

[32] Smayda, T.J., 1990. Novel and nuisance phytoplankton blooms in the sea: evidence for a global epidemic. In: Toxic Marine Phytoplankton (Graneli E, Sundstrom B, Edler L, Anderson DM, eds). New York: Elsevier, pp: 29-40.

[33] Pearl, H.W., D.R. Whitall, 1999. Anthropogenically-driven atmospheric nitrogen deposition, marine eutrophication and harmful algal bloom expansion: is there a link? Ambio, 28: 307-311.

[34] Reigman, R., 1998. Species composition of harmful algal blooms in relation to macronutrient dynamics. In: Physiological Ecology of Harmful Algal Blooms (Anderson DM, CembellaAD, Hallegraeff GM, eds). New York:Springer-Verlag, pp: 475-488.

[35] Glibert, P.M., D.M. Anderson, P. Gentien, E. Graneli, K.G. Sellner, 2005. The global complex phenomena of harmful algae. Oceanography, $18(2)$ : $136-147$.

[36] Lewitus, A.J., R.A. Horner, D.A. Caron, E. Garcia-Mendoza, B.M. Hickey, M. Hunter and J.F. Tweddle, 2012. Harmful algal blooms along the North American west coast region: History, trends, causes, and impacts. Harmful Algae, 19: 133-159.

[37] Heather, L., 2013. Toxic algae bloom on Lake Erie a sign of things to come: experts available in http://globalnews.ca/news/444661/massive-algae-bloom-onlake-erie-a-sign-of- things-to-come-experts/. Retrieved 29 June 2015.

[38] Causes and Effects of Ocean Pollution, available in http://www.conserve-energy-future.com/causes-and-effects-of-ocean-pollution.php. Retrieved.

[39] Mohd, S.N., N.M. Majid, N.A.M. Shazili and A. Abdu, 2013. Assessment of Melaleucacajuputi as heavy metals phytoremediator for sewage sludge contaminated soil. American Journal of Applied Sciences, 10(9): 1087.

[40] Duraisamy, A. and S. Latha, 2011. Impact of pollution on marine environment-A case study of coastal Chennai. Indian Journal of Science and Technology, 4(3): 259-262.

[41] Gasull, A., X. Fabregas, J. Jimenez, F. Marqués, V. Moreno and M.A. Herrero, 2002. Oil spills detection in SAR images using mathematical morphology. In Signal Processing Conference, 2002 11th European (pp. 1-4). IEEE.

[42] Katalay, S., and H. Parlak, 2004. The effects of pollution on haematological parameters of black goby (Gobiusniger L., 1758) in Foça and Aliağa Bays. EÜ Su Ürünleri Dergisi, 21(1-2): 113-117.

[43] Kocasoy, G., 1989. The relationship between coastal tourism, sea pollution and public health: a case study from Turkey. Environmentalist, 9(4): 245-251.

[44] Safari, M., M.P. Zakaria, C.A.R. Mohamed, N.H. Lajis, K. Chandru, P.S. Bahry and S. Anita, 2010. The history of petroleum pollution in Malaysia; urgent need for integrated prevention approach. Environ Asia, 3: 131-142.

[45] Ngah, M.S.Y.C., M. Hashim, N. Nayan, Z.M. Said and M.H. Ibrahim, 2012. Marine Pollution Trend Analysis of Tourism Beach in Peninsular Malaysia. World Applied Sciences Journal, 17(10): 1238-1245.

[46] Sarkar, A., P.M. Tegur, S. Jana and P.V.S.S.D.P. Rao, 2011. Determination of Acetyl cholinesterase activities in marine gastropod (Morulagranulata) as a biomarker of neurotoxic contaminants along the Goan coast. 